\title{
ASSESSING STUDENTS' HIGHER-ORDER THINKING SKILLS: KNOWLEDGE AND PRACTICES OF CHEMISTRY TEACHERS IN VOCATIONAL SENIOR SECONDARY SCHOOLS
}

\author{
Elin Driana ${ }^{1}$, Ary Susilowati ${ }^{2}$, Ernawati ${ }^{3,}{ }^{\text {, }}$, Abd. Rahman A. Ghani ${ }^{4}$ \\ 1, 2, 3,4 Graduate School of University of Muhammadiyah Prof. Dr. HAMKA, Jl. Warung Buncit Raya No. 17, Pancoran \\ Jakarta Selatan 12790, Indonesia \\ E-mail: ernawati.pep@uhamka.ac.id * \\ *Corresponding Author
}

\begin{abstract}
The success of efforts in developing students' higher-order thinking skills (HOTS) to face the complex challenges in the 21 st century also depends on how teachers implement classroom assessments. Studies on teachers' knowledge and practices have been conducted at different levels of education. However, studies that involved teachers in vocational senior secondary schools are still limited. Therefore, this qualitative study aimed at exploring chemistry teachers' knowledge of HOTS, their assessment practices, and the barriers encountered. Ten chemistry teachers from three public and six private vocational senior secondary schools in South Jakarta were involved in this study. Data were collected through semi-structured interviews conducted between August and September 2019. The findings revealed that almost all chemistry teachers believed that providing students in vocational senior secondary schools with HOTS was essential. However, knowledge of HOTS among most teachers was still inadequate, contributing to their unpreparedness in assessing the skills. Misunderstanding about higher-order thinking was also revealed, such as associating higher-order thinking with item difficulties. The teachers in this study considered students' factors as barriers in cultivating HOTS in chemistry learning in vocational senior secondary schools, such as lack of motivation, low academic ability, and lack of reading habits. The teachers also mentioned the shortage of facilities as another barrier that inhibited their efforts in fostering HOTS in chemistry learning. Proper teacher professional development programs are needed to increase teachers' understanding of HOTS assessment and help them develop various strategies for fostering HOTS among vocational senior secondary school students.
\end{abstract}

Keywords: assessment, chemistry education, higher-order thinking skills, teacher's knowledge, vocational school

\section{INTRODUCTION}

Fostering students' higher-order thinking skills (HOTS) for preparing them to face more complex problems in the future has become the aim of education in many countries. That aim is reflected in the documents of educational policies in various countries that emphasize the need for change in curriculum, learning, and assessment to develop students' HOTS [1], [2]. Equipping students with HOTS can help them apply the knowledge in situations that they have never faced before [3].

Since the past few decades, efforts to reform science education have been made by emphasizing scientific literacy and HOTS [4]. The learning of science aims to assist students to develop the skills of higher-order thinking, critical thinking, asking significant questions, reasoning, and solving problems [5]. FitzPatrick and Schulz [6] summarized that "Higher-order and critical thinking in science include developing research questions, forming hypotheses, designing experiments or investigations, analyzing and interpreting data, drawing conclusions, and forming scientific explanation."

Higher-order thinking skills have also become a concern in the learning of chemistry. The development of HOTS in the learning of chemistry "can help students understand basic principles of chemistry that they also encounter in everyday life, and to make personal, social, economic decisions" [7]. However, chemistry learning is considered to be overloaded with materials so that it emphasizes memorizing the 
materials instead of meaningful and relevant learning [8], [9].

Chemistry is a mandatory lesson for vocational senior secondary school students in Indonesia who choose the subject areas of technology and engineering, health, agribusiness and agrotechnology, and fisheries and maritime. The competencies to acquire by vocational senior secondary school students as stated in the Content Standard [10] have included HOTS, such as formulating problems and making hypotheses; planning and conducting experiments by using different variables; writing the results of observation, processing and presenting the data in the form of tables and graphs.

Developing students' critical thinking, creativity, and problem-solving is also crucial for vocational school students to prepare them for the rapid change in the workplace due to technology development [11]. Vocational school students who are competent in HOTS are better prepared for work [12].

The success of efforts to enhance students' HOTS is also affected by assessment practices. Assessments significantly impact learning and teaching, such as determining the content that will be taught and how the learning process will happen [13], [14]. The students' chance of showing their learning outcomes will be higher if there is a connection between learning activities, assessments, and learning targets as written in curriculum documents [6], [15].

Assessments can be used to promote students' HOTS by developing assessment instruments that emphasize those skills [5], [16]. Higher-order thinking assessments measure students' ability to solve a new problem by applying the knowledge they have learned, explaining the phenomenon scientifically and constructively, and using scientific inquiry skills [2]. Assessing students using higher-order thinking assessment instruments will create an environment that encourages them to practice their HOTS and to master the learned materials [15]. Besides, many studies have shown that assessment of HOTS can increase students' achievements and motivation to learn [17].

Efforts to develop students' HOTS are also determined by teachers' understanding of HOTS and its implementation in the classrooms [5]. However, teachers at different levels of education still face challenges in applying the assessment of HOTS. Their assessment instruments are still dominated by items measuring lower-order thinking skills [16], [18], [19]. Moreover, teachers often assume that the assessment instruments they made already assessed HOTS, but they only assessed lowerorder thinking skills [18].

Studies on teachers' knowledge and practices on HOTS have been conducted at different levels of education, such as from kindergarten to grade 9 [20], primary schools [1], [18], [21], junior secondary schools [22], junior secondary and senior secondary schools [23], and senior secondary schools [24]. However, studies focusing on teachers' knowledge and practices of HOTS in vocational senior secondary schools are still limited. The success of efforts to provide vocational senior secondary school students with HOTS also depends on teachers' abilities to develop those skills, including through the assessment activities. Understanding chemistry teachers' knowledge of HOTS and its implementation in assessing their students would help plan programs for developing teachers' abilities in fostering students' HOTS.

Therefore, this research explored teachers' knowledge of HOTS, teachers' understanding of HOTS assessment, teachers' assessment practices, and the barriers encountered in vocational senior secondary schools.

\section{METHOD}

This study adopted a qualitative approach because it was suitable for exploring chemistry teachers' knowledge of HOTS and its assessment, their assessment practices, and the 
barriers they encountered. This study involving ten chemistry teachers from three public and six private vocational senior secondary schools in South Jakarta. Nine teachers participating in this study were females, and one was male. The ages of the teachers ranged from 23 years old to 71 years old. Two teachers were below 30 years old; three teachers were between 30 and 50 years old, and five teachers were above 50 years old. Their teaching experiences were between 2 and 30 years. Two teachers had teaching experiences for less than five years, two teachers between six and fifteen years, and six teachers for more than 15 years. In terms of educational background, three teachers attained a master's degree (S2): two in chemistry education and one in chemistry. Seven teachers had a bachelor's degree (S1): three in chemistry education, two in chemistry, one in science, and one in mechanical engineering. The characteristics of the teachers participating in this study are presented in Table 1 .

Table 1. Characteristics of the Teachers

\begin{tabular}{|c|c|c|c|}
\hline No. & Characteristic & $\mathrm{N}$ & $\%$ \\
\hline \multirow[t]{3}{*}{1.} & Gender & & \\
\hline & Male & 1 & $10 \%$ \\
\hline & Female & 9 & $90 \%$ \\
\hline \multirow[t]{4}{*}{2.} & Age & & \\
\hline & $<30$ years old & 2 & $20 \%$ \\
\hline & $30-50$ years old & 3 & $30 \%$ \\
\hline & $>50$ years old & 5 & $50 \%$ \\
\hline \multirow[t]{3}{*}{3.} & $\begin{array}{l}\text { Years of Teaching } \\
<5 \text { years }\end{array}$ & 2 & $20 \%$ \\
\hline & $6-15$ years & 2 & $20 \%$ \\
\hline & $>15$ years & 6 & $60 \%$ \\
\hline \multirow[t]{3}{*}{4.} & Level of Education & & \\
\hline & S1 (Bachelor's Degree) & 7 & $70 \%$ \\
\hline & S2 (Master's Degree) & 3 & $30 \%$ \\
\hline \multirow[t]{3}{*}{5.} & $\begin{array}{l}\text { Alignment between Subject } \\
\text { Teaching and Educational } \\
\text { Background }\end{array}$ & & \\
\hline & Linear & 9 & $90 \%$ \\
\hline & Not Linear & 1 & $10 \%$ \\
\hline
\end{tabular}

The data collection employed a semistructured interview because of its strength in collecting comprehensive and systematic data [25] and in revealing how informants express their thoughts and interpret their experiences [26]. Eleven main questions had been prepared as a guideline, but the interviewer still had the freedom to probe and elaborate on the questions during the interview.

The interviews were conducted after permission was granted by Region I and II of the Education Office of South Jakarta. The second author of this article, who had been a chemistry teacher for about 16 years, interviewed all the teachers individually in their schools in August and September 2019. With the approval of the teachers participating in this study, all the interviews were audio-recorded and transcribed. The second author did all the transcriptions. All authors read each transcription from the beginning to the end for coding and categorizing.

\section{RESULTS AND DISCUSSION}

The interview data analysis identified five categories: teachers' knowledge of higher-order thinking skills, teachers' beliefs about higherorder thinking skills, teachers' understanding of higher-order thinking assessments, teachers' assessment practices, and teachers' barriers in assessing HOTS.

\section{Teachers' Knowledge of Higher-Order Thinking Skills}

The majority of teachers who participated in this study recognized the term HOTS. However, two teachers had not heard the term. It is surprising because the policy documents of the Ministry of Education and Culture of the Republic of Indonesia, such as the Graduate Competency Standard, the Content Standard, and the Process Standard, have highlighted the importance of fostering students' HOTS. Moreover, in the past few years, items measuring HOTS have been integrated into the national examination for ninth-grade and twelfth-grade students and the national-based school exam for sixth-grade students so that teachers were required to develop student thinking ability through learning and assessment in the classrooms. 
Three out of ten teachers linked HOTS with the three highest cognitive levels of the revised Bloom's taxonomy: analyze, evaluate, and create, but one of them (Teacher 1) only mentioned analyze and create.

"In my understanding, HOTS is higherorder thinking skills. The students are taught not only to understand the questions or to memorize but also to analyze and to create. It is from Bloom's taxonomy. There are six levels, but I forgot the other levels." (Teacher 1)

"HOTS is higher-order thinking skills, in which students can think at the level of C4, C5, and C6." (Teacher 3)

"HOTS is higher-order thinking skills. It means thinking at higher levels. Therefore, the items are not only about explaining something but also analyzing. It is from C4 to C6." (Teacher 5)

Besides referring to the revised Bloom's taxonomy, teachers also conceptualized HOTS as "critical thinking and creativity" (Teacher 7), and "critical thinking for problem-solving" (Teacher 3). These conceptions refer to the definitions of higher-order thinking in three categories by Brookhart [17]: transfer, critical thinking, and problem-solving.

Three teachers (Teacher 4, Teacher 6, and Teacher 10) associated higher-order thinking with the level of difficulty, as represented by the following statement.

"HOTS are higher-order thinking skills. So, it is about understanding the questions but with a higher level of difficulty. It is more or less like that." (Teacher 6)

Teachers' misconception of HOTS as difficult items also emerged in earlier studies [18], [24]. According to Brookhart [17], it is crucial to differentiate the level of complexity from the level of difficulty in assessing HOTS because misconceptions about the two different concepts will result in items that fail to serve their intended purposes. Complexity is whether an item measures higher or lower-order thinking, while difficulty is whether an item is considered hard or easy [17]. Ideally, as the level of complexity increases, the item difficulty also increases [27]. However, this is not necessarily the case. For example, a study conducted by Schneider et al. [27], utilizing a grade 4 mathematics test that consisted of 64 multiple-choice items and a grade 8 mathematics test that consisted of 62 multiplechoice items, demonstrated that the cognitive complexity and contextual frameworks were not always associated with item difficulty.

\section{Teachers' Beliefs about Higher-Order Thinking Skills}

Most teachers indicated their belief that providing students with HOTS is essential for students' future. Among the reasons are to prepare students to face the challenges of the 21st century (Teacher 1, Teacher 5) and the Fourth Industrial Revolution (Teacher 1), to teach students to think critically (Teacher 3, Teacher 7, Teacher 9), creatively (Teacher 3, Teacher 9), and innovatively (Teacher 3), and to solve problems (Teacher 7), as stated in the following excerpts:

"In my opinion, it is very important because it automatically teaches students in cognitive, psychomotor, and attitude aspects, especially for facing the 21st century and the 4.0 Era." (Teacher 1)

"HOTS assessment is very important because it can train students to think critically, creatively, and innovatively." (Teacher 3)

"Actually, it is very important to help students think critically and solve problems, and students know whether they have achieved each basic competency." (Teacher 7) 
These findings support previous studies of teachers' views on the importance of fostering HOTS, such in primary schools [18], from kindergarten to junior secondary schools [20], and senior secondary schools [2]. However, one of the teachers questioned the importance of HOTS for vocational school students who mostly enter the workforce right after graduating instead of pursuing a higher level of education, as shown in the following excerpt:

"It is not important for vocational school students. I prefer explaining simple things related to students ' real life, such as, about the danger of free radicals." (Teacher 10$)$

The teacher's view does not comply with recent development on the importance of providing students, including those at the vocational schools, with HOTS to prepare them for entering the workplace in the 4.0 Industrial Revolution era [11], [12].

\section{Teachers' Understanding of HOTS Assessment}

The interview results showed that teachers' understanding of HOTS assessment is a reflection of their knowledge about HOTS. Teachers mostly linked higher-order thinking assessment with the revised Bloom's Taxonomy, as stated in the following excerpts:

"As I have explained before, HOTS assessment is whether students can analyze, evaluate, and create." (Teacher 1)

"Students are expected to solve questions that require them to analyze, evaluate, and create to make them more creative." (Teacher 3 )

"HOTS assessment is the C5 and C6 of the cognitive level." (Teacher 9)

Brookhart [17] categorized assessment of various aspects of HOTS into five categories: assessing analysis, evaluation, and creation; assessing logic and reasoning, assessing judgment, assessing logic and reasoning, and assessing creativity and creative thinking. Most teachers in this study referred to the aspects in the first category, which associate with the three highest levels of the cognitive dimension of the revised Bloom's taxonomy. Assessing other aspects of HOTS barely emerged during the interviews. Some teachers viewed HOTS assessments as difficult items as expressed below:

"In my opinion, HOTS questions are more difficult. There are several stages in solving HOTS questions." (Teacher 10)

The teachers' limited understanding of HOTS assessment might be attributed to the fact that none of the teachers participating in this study had attended a training program about the assessment of HOTS. Effective teacher professional development programs to provide teachers with the knowledge and skills needed are essential for improving student achievement in science [28]. A comparative study involving German and Swedish teachers revealed that teachers viewed their assessment practices and opportunities to collaborate with other teachers are more important than formal professional development in enhancing their assessment knowledge [29].

\section{The Practices of HOTS Assessment}

In responding to the questions about enacting HOTS assessments in the classrooms, seven teachers stated that they had included items measuring HOTS in their assessment instruments. On the other side, two teachers stated that HOTS items had not been included in their assessment instruments because they considered that their students were not ready to solve complex questions.

"Not yet because we still need to motivate students to learn chemistry. 
We have to educate more than to teach because chemistry is not tested in the national exams. I still focus on LOTS and MOTS. I don't include HOTS questions because HOTS questions are usually designed for the national college entrance test, while vocational students usually want to work after graduating. It is still on the level of understanding, remembering." (Teacher 1)

The other teacher, Teacher 5, stated a similar response:

"Not yet because the students are not ready." (Teacher 5)

Previous studies also revealed similar findings that teachers were uncertain about teaching and assessing higher-order thinking to low achieving students [20]. However, despite their doubt, the teachers still believed that exposure to higher-order thinking was beneficial to all students. In designing the assessment instruments, two teachers stated that they adjusted the questions with students' level of ability, as expressed below:

"I use varied questions by adjusting to students' level of ability. If students have different levels of ability, the questions need to vary so that students' scores can achieve the KKM (the minimum level of mastery). It means there are easy, moderate, and difficult items." (Teacher 2)

"The implementation is like I gave students questions by adjusting the level of difficulty with their ability level." (Teacher 6)

Regarding the form of the assessment instruments, most teachers mentioned multiplechoices and essays. Two teachers stated that they also included HOTS in laboratory activities.

"The forms of instruments vary. There are multiple-choice questions, essays, and laboratory activities for the graduation testing or depending on the content and the time." (Teacher 2)

"For students who are majoring in agriculture, the HOTS assessment is mostly implemented in the field; how students use critical thinking to solve problems." (Teacher 3)

"Using multiple-choice questions, essays, question and answer, attitude assessments, and assignments." (Teacher 4)

"Assessing HOTS can be in the form of a portfolio, then attitude assessment." (Teacher 7)

\section{The Barriers in Assessing HOTS}

The interview data also revealed that almost all teachers considered students as the main barrier in assessing HOTS. One of the barriers is students' low ability, as stated in the following excerpt:

"Students' ability does not support the implementation of HOTS." (Teacher 5).

The curriculum documents in many countries, including Indonesia, expect all students to develop HOTS. Previous studies also indicated that most teachers believed that HOTS should be acquired by all students [2], [20]. However, teachers also realize the barriers in developing HOTS among low-ability students [2]. Another challenge is students' low motivation, as stated below:

"Students are not active, and they do not have the motivation to learn." (Teacher 2)

"The obstacle is how to motivate students to be more active in learning because vocational students are not enthusiastic about learning chemistry." (Teacher 3)

"The challenge is from the students because of their low motivation to learn." (Teacher 6) 
The lack of motivation among vocational senior secondary school students in learning chemistry has been a concern of earlier studies. Failure to demonstrate how chemistry is related to daily life, the overloaded teacher material, and teacher-centered learning are among factors that contribute to students' low motivation to learn chemistry [8], [30]. The lack of students' motivation in learning chemistry might also be explained by the teaching method that emphasized memorization with limited exposures to the development of a deeper understanding and problem-solving ability [8], [31]. A study conducted among senior secondary school students in Sweden indicated that students' motivation to learn chemistry increases when they found the learning materials are both relevant, especially to their personal life, and interesting [32]. Another teacher linked students' low motivation to the fact that chemistry is not a subject tested in the national examination.

"The obstacle is that it is difficult to motivate students to learn chemistry. All of the students are males. Their purpose is to get a job directly after graduating from school, and chemistry is not part of the national exam. That is the obstacle." (Teacher 1)

Indonesia has a long history of high-stake testing for determining students' graduation from each level of education, including from primary schools, and for selecting students to continue their study to a higher level of education. The use of the national examination results for graduation purposes has been abolished since 2015. However, students were still required to take the national examination until 2020. Due to the Covid-19 pandemic, the administration of the 2020 national examination was annulled. It seems that the existence of the national examination still serves as a motivating factor. Cultivating students' intrinsic motivation to learn seems still a challenge for Indonesian teachers.
On the other hand, the absence of a national examination to determine student graduation might allow teachers to engage students more in learning and assessment activities that promote the development of HOTS. Preparation for high-stakes tests, such as national examination, often alter the learning process from active and meaningful learning to drilling. For example, a study conducted in Israel revealed how teachers changed their instruction strategies from activities that motivate students to develop their active thinking to practice the exam questions due to the pressure to increase students' scores in a limited amount of time [2].

Two teachers (Teacher 8 and Teacher 10) mentioned the lack of reading ability as an obstacle in assessing HOTS. Previous studies, such as among teachers at general senior secondary schools in Jakarta [24] and teachers from kindergarten to grade 9 in Newfoundland and Labrador, Canada, also revealed the same view. The HOTS assessments are also characterized by introductory materials, such as texts [17] that they need to comprehend before answering the questions. The lack of reading ability can inhibit students in engaging from HOTS assessment activities.

Besides factors related to students, the interview results also indicated factors related to teachers that impede the HOTS assessments. Teachers in this study found difficulties in developing instruments for assessing HOTS that confirmed findings from previous studies [18], [19], [24]. For example, a study by Dahlan et al. [19] among 45 economics teachers from 27 public senior secondary schools in Bandung showed that $47 \%$ of the teachers found difficulty in formulating HOTS questions. Further descriptions demonstrated that the teachers faced difficulty in constructing HOTS assessment instruments either in the form of multiple-choice, essay, or oral questions. One of the factors that might contribute to teachers' difficulties in assessing HOTS is their limited understanding of HOTS and its assessment. 
The scarcity of school facilities, such as chemistry laboratories, is another challenge. Even in some schools, as stated by Teacher 1, Teacher 5, and Teacher 6, chemistry laboratories are not available. The availability of laboratories provides opportunities for teachers to implement learning and assessment activities that promote the development of HOTS. For example, a study demonstrated that chemistry laboratory activities adopting inquiry-based learning can encourage students to think creatively, improve their ability in solving chemistry-related problems, and relate the concepts they learned with real-life contexts [33]. Besides real laboratories, studies also showed the benefits of virtual laboratories in providing opportunities for students to engage in meaningful activities that nourish HOTS, such as the Microcomputer-based Laboratory (MBL) [34] and Computerized Molecular Modeling (CMM) software packages [35]. As the implication, chemistry teachers need to be more familiar with and confident in utilizing the advantages of technology development by designing and facilitating a learning environment that promotes HOTS.

\section{CONCLUSION}

This study explored the assessment of HOTS among chemistry teachers in Indonesian vocational senior secondary schools. The findings showed that almost all chemistry teachers participated in this study believed that fostering higher-order thinking skill is essential for vocational senior secondary school students to prepare them for the changing workplace in the 21 st century. However, teachers' knowledge of HOTS was still inadequate, which resulted in their uncertainty in assessing HOTS. They were not sure in articulating the meaning of HOTS and illustrating how they implemented the assessment of HOTS in the context of chemistry. Misunderstanding about higherorder thinking was also revealed, such as associating higher-order thinking with difficult items. The lack of teachers understanding about teaching and assessing HOTS could be explained by the fact that none of the teachers participating in this study had attended a training program about HOTS. It is also essential to question whether teacher preparation programs have included pedagogical knowledge about teaching and assessing HOTS.

The teachers in this study considered factors related to students as barriers in cultivating HOTS in chemistry for vocational senior secondary schools, such as lack of motivation, low academic ability, and lack of reading habits. The teachers also mentioned the shortage of facilities as another barrier that inhibits their efforts in fostering HOTS in chemistry learning. Proper teacher professional developments are needed to enhance teachers' understanding of HOTS assessment. Teachers also need opportunities to share and learn among them to enrich their strategies in fostering students' HOTS.

\section{ACKNOWLEDGMENT}

The research is supported by the Master's Thesis Grant of the Ministry of Research and Technology, the Republic of Indonesia. The authors are grateful to the teachers who participated in this study. We would also like to thank the Institute of Research and Development, the University of Muhammadiyah Prof. Dr. HAMKA, for supporting and facilitating the research.

\section{REFERENCES}

[1] S. S. Yeung, "Conception of teaching higher order thinking: perspectives of Chinese teachers in Hong Kong," Curric. J., vol. 26, no. 4, pp. 553-578, 2015.

[2] A. Zohar and V. A. Agmon, "Raising test scores vs. teaching higher order thinking (HOT): senior science teachers' views on how several concurrent 
policies affect classroom practices," Res.

Sci. Technol. Educ., vol. 36, no. 2, pp. 243-260, 2018, doi: 10.1080/02635143.2017.1395332.

[3] S. Toledo and J. M. Dubas, "Encouraging higher-order thinking in general chemistry by scaffolding student learning using Marzano's taxonomy," J. Chem. Educ., vol. 93, no. 1, pp. 64-69, 2016, doi: 10.1021/acs.jchemed.5b00184.

[4] Y. J. Dori, V. Dangur, S. Avargil, and U. Peskin, "Assessing advanced high school and undergraduate students' thinking skills: The chemistry-from the nanoscale to microelectronics module," J. Chem. Educ., vol. 91, no. 9, pp. 13061317, 2014, doi: 10.1021/ed500007s.

[5] M. Barak and Y. J. Dori, "Enhancing higher order thinking skills among inservice science teachers via embedded assessment," J. Sci. Teacher Educ., vol. 20, no. 5, pp. 459-474, 2009, doi: 10.1007/s10972-009-9141-z.

[6] B. FitzPatrick and H. Schulz, "Do curriculum outcomes and assessment activities in science encourage higher order thinking?," Can. J. Sci. Math. Technol. Educ., vol. 15, no. 2, pp. 136-154, 2015, doi: 10.1080/14926156.2015.1014074.

[7] M. Aksela, Supporting meaningful chemistry learning and higher-order thinking through computer-sssisted inquiry: A design research approach. 2005.

[8] S. Avargil, O. Herscovitz, and Y. J. Dori, "Teaching thinking skills in context-based learning: teachers' challenges and assessment knowledge," J. Sci. Educ. Technol., vol. 21, no. 2, pp. 207-225, 2012, doi: 10.1007/s10956011-9302-7.

[9] M. Overman, J. D. Vermunt, P. C. Meijer, A. M. W. Bulte, and M. Brekelmans, "Textbook questions in context-based and traditional chemistry curricula analysed from a content perspective and a learning activities perspective," Int. J. Sci. Educ., vol. 35, no. 17, pp. 2954-2978, 2013, doi: 10.1080/09500693.2012.680253.

[10] Kementerian Pendidikan dan Kebudayaan, Salinan Lampiran Peraturan Menteri Pendidikan dan Kebudayaan Nomor 21 Tahun 2016 tentang Standar Isi Pendidikan Dasar dan Menengah. 2016.

[11] M. Samani, B. A. W. Putra, R. Rahmadian, and J. N. Rohman, "Learning strategy to develop critical thinking, creativity, and problem-solving skills for vocational school students," $J$. Pendidik. Teknol. dan Kejuru., vol. 25, no. 1, pp. 36-42, 2019, doi: 10.21831/jptk.v25i1.22574.

[12] A. Hasan and P. Pardjono, "The correlation of higher order thinking skills and work readiness of vocational high school students," J. Pendidik. Teknol. dan Kejuru., vol. 25, no. 1, pp. 52-61, Apr. 2019, doi: 10.21831/jptk.v25i1.19118.

[13] J.-A. Baird, D. Andrich, T. N. Hopfenbeck, and G. Stobart, "Assessment and learning: fields apart?," Assess. Educ. Princ. Policy Pract., vol. 24, no. 3, pp. 317-350, 2017, doi: https://doi.org/10.1080/0969594X.2017. 1319337.

[14] Samritin and Suryanto, "Developing an assessment instrument of junior high school students' higher order thinking skills in mathematics," Res. Eval. Educ., vol. 2, no. 1, pp. 92-107, 2016, doi: :http://dx.doi.org/10.21831/reid.v2i1.826 8.

[15] J. L. Jensen, M. A. McDaniel, S. M. Woodard, and T. A. Kummer, "Teaching to the test...or testing to teach: Exams requiring higher order thinking skills encourage greater conceptual understanding," Educ. 
Psychol. Rev., vol. 26, no. 2, pp. 307329, 2014, doi: 10.1007/s10648-0139248-9.

[16] S. Hamdi, I. A. Suganda, and N. Hayati, "Developing higher-order thinking skill (HOTS) test instrument using Lombok local cultures as contexts for junior secondary school mathematics," Res. Eval. Educ., vol. 4, no. 2, pp. 126-135, 2018, doi: 10.21831/reid.v4i2.22089.

[17] S. M. Brookhart, How to assess higherorder thinking skills in your classroom. Alexandria, VA: ASCD, 2010.

[18] E. Driana and Ernawati, "Teachers' understanding and practices in assessing higher order thinking skills at primary schools," Acitya J. Teach. Educ., vol. 1, no. 2, pp. 110-118, 2019.

[19] D. Dahlan, L. Permana, and $M$. Oktariani, "Teacher's competence and difficulties in constructing HOTS instruments in economics subject," Cakrawala Pendidik., vol. 39, no. 1, pp. 111-119, 2020.

[20] H. Schulz and B. FitzPatrick, "Teachers' understandings of critical and higher order thinking and what this means for their teaching and assessments," Alberta J. Educ. Res., vol. 62, no. 1, pp. 61-86, 2016.

[21] W. M. W. Yusoff and S. C. Seman, "Teachers' knowledge of higher order thinking and questioning skills: a case study at a primary school in Terengganu, Malaysia," Int. J. Acad. Res. Progress. Educ. Dev., vol. 7, no. 2, pp. 45-63, 2018, doi: 10.6007/ijarped/v7-i2/4120.

[22] H. Retnawati, H. Djidu, Kartianom, E. Apino, and R. D. Anazifa, "Teachers' knowledge about higher-order thinking skills and its learning strategy," Probl. Educ. 21st Century, vol. 76, no. 2, pp. 215-230, 2018.

[23] A. Zohar and N. Schwartzer, "Assessing teachers' pedagogical knowledge in the context of teaching higher-order thinking," Int. J. Sci. Educ., vol. 27, no.
13, pp. 1595-1620, 2005, doi: 10.1080/09500690500186592.

[24] N. Nurmawati, E. Driana, and E. Ernawati, "Pemahaman guru kimia SMA tentang penilaian kemampuan berpikir tingkat tinggi dan implementasinya," EDUSAINS, vol. 12, no. $2,2020$.

[25] J. R. Fraenkel and N. E. Wallen, How to Design and Evaluate Research in Education, 6th ed. New York: Mc GrawHill International Edition, 2007.

[26] J. A. Hatch, Doing Qualitative Research in Education Settings. Albany: State University of New York Press, 2002.

[27] M. C. Schneider, K. L. Huff, K. L. Egan, M. L. Gaines, and S. Ferrara, "Relationships among item cognitive complexity, contextual demands, and item difficulty: implications for achievement-level descriptors," Educ. Assessment, vol. 18, pp. 99-121, 2013, doi: 0.1080/10627197.2013.789296.

[28] S. Dogan, R. Pringle, and J. Mesa, "The impacts of professional learning communities on science teachers' knowledge, practice and student learning: a review," Prof. Dev. Educ., vol. 42, no. 4, pp. 569-588, 2016, doi: 10.1080/19415257.2015.1065899.

[29] E. Forsberg and W. Wermke, "Knowledge sources and autonomy: German and Swedish teachers' continuing professional development of assessment knowledge," Prof. Dev. Educ., vol. 38, no. 5, pp. 741-758, 2012, doi: 10.1080/19415257.2012.694369.

[30] I. B. Yuliastini, S. Rahayu, F. Fajaroh, and N. Mansour, "Effectiveness of pogil with ssi context on vocational high school students' chemistry learning motivation," J. Pendidik. IPA Indones., vol. 7, no. 1, pp. 85-95, 2018, doi: 10.15294/jpii.v7i1.9928.

[31] H. Čtrnáctová, L. Čtrnáctová, and P. Šmejkal, "IBSE in chemistry education testing students' skills and teacher 
training," Lumat Int. J. Math, Sci. Technol. Educ., vol. 3, no. 4, pp. 556-567, 2015, doi: 10.31129/lumat.v3i4.1023.

[32] K. Broman, S. Bernholt, and C. Christensson, "Relevant or interesting according to upper secondary students? Affective aspects of context-based chemistry problems," Res. Sci. Technol. Educ., vol. 00, no. 00, pp. 1-21, 2020, doi: 10.1080/02635143.2020.1824177.

[33] G. V. Madhuri, V. S. S. N. Kantamreddi, and L. N. S. Prakash Goteti, "Promoting higher order thinking skills using inquiry-based learning," Eur. J. Eng.
Educ., vol. 37, no. 2, pp. 117-123, 2012, doi: 10.1080/03043797.2012.661701.

[34] M. Aksela, "Engaging students for meaningful chemistry learning through Microcomputer-based Laboratory (MBL) inquiry," Educ. Química, vol. 0, no. 09, pp. 30-37-37, 2011, doi: 10.2436/eduq.v0i09.60329.

[35] Y. J. Dori and Z. Kaberman, "Assessing high school chemistry students' modeling sub-skills in a computerized molecular modeling learning environment," Instr. Sci., vol. 40, no. 1, pp. 69-91, 2012, doi: 10.1007/s11251011-9172-7. 